\title{
Green-shell bean production in Puerto Rico at different planting dates ${ }^{1,2}$
}

\author{
James S. Beaver ${ }^{3}$ and Obed Román-Hernández
}

\begin{abstract}
Field experiments were conducted at the Isabela and Fortuna substations during a 4-year period to measure the whole pod and green-shell yields of five white-seeded bean genotypes planted at different dates. Results from this study show that green-shell beans can be produced in Puerto Rico over a wide range of planting dates. The greatest yields were produced when beans were planted from October to December. Results from a yield stability analysis show that whole pod yields tended to be lower and more variable when beans were planted during the warm and humid summer months. However, higher prices during the summer help to offset the greater risk associated with green-shell bean production during this time of year. The variety Arroyo Loro had the greatest overall yield and the most yield stability. Early maturity and disease susceptibility contributed to the poor yield stability of the variety Cuarentena. Since whole pod yield was positively and highly correlated with green-shell yield, whole pod yields can be used by bean researchers to predict green-shell yield.
\end{abstract}

\section{RESUMEN}

Producción de habichuelas verdes en Puerto Rico en distintas épocas de siembra.

Durante 4 años se hicieron experimentos de campo en las subestaciones de Isabela y Fortuna para medir el rendimiento de vainas enteras y granos frescos de cinco genotipos de habichuela blanca sembrados en diferentes épocas. Los resultados indican que en Puerto Rico se puede producir habichuelas en una amplia gama de épocas de siembra. Los mayores rendi-mientos se obtuvieron cuando las habichuelas se sembraron entre octubre y diciembre. El análisis de estabilidad de rendimiento mostró que los rendimientos de las vainas enteras fueron más bajas y variables cuando se sembró en el verano, los meses más cálidos y húmedos. Sin embargo, los precios de la habichuela verde son mayores durante el verano. La variedad Arroyo Loro produjo los rendimientos más altos y los más estables. La precocidad y susceptibilidad a las enfermedades redujo la estabilidad del rendimiento de la variedad Cuarentena. Hubo una correlación positiva y alta entre los rendimientos de vainas enteras y los rendimientos de habichuelas frescas. Esto les permite a los investigadores en habichuela utilizar el rendimiento de vainas enteras para predecir el rendimiento de vainas frescas.

'Manuscript submitted to Editorial Board 9 February 1993.

*This research was supported by Puerto Rico Agricultural Experiment Station Hatch

Project H-345 entitled "Breeding dry beans for Puerto Rico."

"Associate Professor, Department of Agronomy and Soils.

'Research Associate, Department of Agronomy and Soils. 


\section{INTRODUCTION}

Green-shell beans (Phaseolus vulgaris L.) are harvested near physiological maturity. Badillo-Feliciano et al. reported that green-shell bean production has several advantages. Green-shell beans can be harvested at least 15 days earlier than dry beans, thus avoiding disease and insect damage that may occur at the end of the growing season. Green-shell beans can be harvested during unfavorable weather conditions. In addition, this short season crop is well suited to rotations or intercropping. Yields of green-shell beans is often $300 \%$ greater than that of dry beans. Moreover, the market value of green-shell beans on a unit of weight basis is twice the value of dry beans. Badillo-Feliciano et al." identified the perishability of green-shell beans as the greatest disadvantage of the crop. Green-shell beans need to be marketed within a few days after harvest. However, there are facilities in Puerto Rico that could be used for canning green-shell beans.

As a fresh market crop, green-shell beans should be produced throughout the year. In Puerto Rico, the performance of dry beans and snap beans at different planting dates has been studied by Guadalupe ${ }^{6}$ and Beaver et al. ${ }^{7,8}$ There are no data, however, concerning the effect of planting date on green-shell bean production. Moreover, the green shell yields of recently released white-seeded varieties and breeding lines such as "Arroyo Loro" have not been compared with traditional whiteseeded varieties such as "Cuarentena."

\section{MATERIALS AND METHODS}

Field experiments were conducted at the Isabela and Fortuna substations. At Isabela, the experiments were planted in October and December 1985; January, October and December 1986; February, June, October and December 1987; and February and June 1988. At Fortuna, the experiments were planted in November and December 1985; March, April and December 1987; and January, May and June 1988. The soil at Isabela is an Oxisol of the Coto series whereas at Fortuna it is a Mollisol of the San Antón series.

Badillo-Feliciano, J, I. Reyes-Soto and J.S. Beaver, 1985. A comparison of yields of common bean at physiological and harvest maturity. J. Agric. Univ. P.R. 69: 19-24.

"Guadalupe, R. 1977. Influencia de la época de siembra en el comportamiento de la habichuela (Phaseolus vulgaris L.). MS Thesis. University of Puerto Rico, Mayaguez.

'Beaver, J.S., J. Badillo-Feliciano and I. Reyes-Soto, 1985. Performance of diy beans grown on the coastal plains of Puerto Rico. J. Agric. Univ. P.R. 69: 125-132.

"Beaver, J.S., O. Román-Hernández and L.E. Rivera, 1988. Dry beans and varying cultural practices at, two Jocations on the coastal plain of Puerto Rico. J. Agric. Uniu. P.R. 72: $521-530$. 
The treatments consisted of five white-seeded bean genotypes. Arroyo Loro is a recently released variety and L-227, 8541-34, 8542-225 are breeding lines. Cuarentena is the variety that has traditionally been used for green-shell bean production. The experimental units consisted of plots that were $5 \mathrm{~m}$ long and $2.4 \mathrm{~m}$ wide. A spacing of $0.6 \mathrm{~m}$ was used between the four rows planted in each experimental unit. Fifty-five seeds were planted in each row. Four-meter lengths of each of the two middle rows were harvested. Approximately $0.5 \mathrm{~m}$ at both ends of each row was considered border and was not harvested. After whole pod yields were recorded, a $1-\mathrm{kg}$ sample of pods were shelled.

A randomized complete block design was used. The effects of genotypes and planting dates were considered fixed. Means of genotypes within a particular planting date were compared by using least significant differences $(P=0.05)$. Regression analyses were used to estimate the stability of green shell yields over planting dates and locations. Correlations coefficients were calculated between green-shell and whole pod yields.

\section{RESULTS AND DISCUSSION}

Arroyo Loro and 8542-225 had the greatest overall whole pod yield, averaging 6748 and $6482 \mathrm{~kg} / \mathrm{ha}$, respectively (Table 1). The whole pod yield of Cuarentena was significantly lower than the mean of the test. Cuarentena also had the lowest regression coefficient and significant deviations from regression. A regression coefficient smaller than 1 indicates that in higher yielding environments a genotype tends to produce lower yields than the other entries. Line 8542-225 tended to produce the greatest yields in higher yielding environments. Early maturity and susceptibility to rust, common bacterial blight and bean common mosaic virus contributed to the less stable yields of Cuarentena. Early maturity does not permit Cuarentena to take full advantage of favorable environmental conditions. Cuarentena has been observed to have premature defoliation due to rust and common blight, which reduces both yield and seed quality. Arroyo Loro has desirable yield stability characteristics, combining high mean yield with an average response to productivity and minimum deviations from regression.

At Isabela, the greatest yields were produced for the October and December-January planting dates (table 2). Arroyo Loro had the best overall performance at the February planting date. The summer was

"Eberhart, S.A. and Russell. 1966. Stability parameters for comparing varieties. Crop Sci. $6: 36-40$. 
TABLE 1.-Mean whole pod yield and yield stability characteristics of five white-seeded. bean genolypes planted in 17 environments in Puerto Rico.

\begin{tabular}{lccc}
\hline Genotype & Whole pod yield & $\begin{array}{c}\text { Regression } \\
\text { coefficient }\end{array}$ & $\begin{array}{c}\text { Deviations from } \\
\text { regression' }\end{array}$ \\
\hline Cuarentena & $k g / h a$ & & \\
Arroyo Loro & 5245 & 0.87 & $817397^{:}$ \\
L227-1 & $6748 \%$ & 0.90 & 498056 \\
8541-34 & 6040 & 1.00 & 478450 \\
$8542-225$ & 6128 & 1.05 & 600631 \\
Mean & $6482^{*}$ & 1.19 & 480082 \\
L.S.D. (0.05) & 6128 & & \\
\hline
\end{tabular}

The pooled error mean square was 76726 .

Significantly greater $(P=0.05)$ than pooled error mean square.

the most problematic season for producing green-shell beans. We were able to harvest only one of three summer plantings at Isabela. Pod yields ranged from $4091 \mathrm{~kg} / \mathrm{ha}$ for L227-1 to $5155 \mathrm{~kg} / \mathrm{ha}$ for $8541-34$ for the June 1987 planting. During the summer season there are higher temperatures and a greater potential for periods of intense rainfall. These environmental conditions reduce pod set and lower seed quality. In recent years, bean golden mosaic virus, a disease which is more prevalent in northwestern Puerto Rico during the summer, has caused losses to commercial growers in Isabela and surrounding municipalities. Although there is greater risk associated with the summer plantings of beans, the potential reward is also greater. Prices for green-shell beans during the summer when pigeon peas are not available are ofter double the price obtained during the winter months. At the Isabela substation, Arroyo Loro had the most consistent performance over different planting dates. Mean whole pod yield of Arroyo Loro ranged from $4967 \mathrm{~kg} / \mathrm{ha}$ for the June 1987 planting date to $9581 \mathrm{~kg} / \mathrm{ha}$ at the December 1985 planting date.

Whole pod yields at the Fortuna substation were greatest for the November and December planting dates (table 2). However, the yields of Cuarentena varied more between years than the other bean genotypes. Arroyo Loro and 8541-34 produced the greatest overall yields for the November and December planting dates. Although mean yields for the January and February planting dates were lower than for the November and December planting dates, all of the bean genotypes produced acceptable yields. As the planting date approached the summer season, there was more variability among years in whole pod yield. 
TABLE 2.-Whole pod yield of five white-seeded bean genotypes tested at the Isabela substation at different planting dates.

\begin{tabular}{ccccccc}
\hline & \multicolumn{7}{c}{ Genotype } \\
\cline { 2 - 7 } $\begin{array}{c}\text { Planting } \\
\text { date }\end{array}$ & Cuarentena & A. Loro & L227-1 & $8541-34$ & $8542-225$ & $\begin{array}{c}\text { L.S.D. } \\
(0.05)\end{array}$ \\
\hline & & \multicolumn{7}{c}{$k g / h a$} \\
Oct. 1985 & 5535 & 7140 & 6266 & 5688 & 7659 & 1260 \\
Oct. 1987 & 7679 & 7159 & 5825 & 7577 & 7696 & 1349 \\
Dec. 1985 & 6931 & 9581 & 7884 & 8077 & 9630 & 1466 \\
Jan. 1986 & 5165 & 5908 & 621.3 & 6462 & 5719 & N.S. \\
Feb. 1987 & 3125 & 5453 & 3327 & 3911 & 3087 & 1119 \\
Feb. 1988 & 4516 & 5933 & 5361 & 4491 & 4766 & N.S. \\
June 1987 & 4734 & 4967 & 4091 & 5155 & 4633 & 1577 \\
\hline
\end{tabular}

For the March to June planting dates, Arroyo Loro consistently produced the highest, or among the highest, mean yields. Because Fortuna receives less rainfall at the beginning of the summer season than Isabela, there may be less risk associated with a summer planting of green shell beans on the southern coastal plain of Puerto Rico.

Green-shell bean yields averaged $2,640 \mathrm{~kg} / \mathrm{ha}$ at Isabela and 2,921 $\mathrm{kg} / \mathrm{ha}$ at the Fortuna substation. This was $44.6 \%$ of whole pod yield at Isabela and $46.6 \%$ of whole pod yield at the Fortuna substation. The

TABLE 3.-Whole pod yield of five white-seeded bean genotypes tested at the Fortuna substation at different planting dates.

\begin{tabular}{ccccccc}
\hline & \multicolumn{5}{c}{ Genotype } \\
\cline { 2 - 7 } $\begin{array}{c}\text { Planting } \\
\text { date }\end{array}$ & Cuarentena & A. Loro & L227-1 & $8541-34$ & $8542-225$ & $\begin{array}{c}\text { L.S.D. } \\
(0.05)\end{array}$ \\
\hline & \multicolumn{7}{c}{ kg/ha } \\
Nov. 1985 & 2622 & 7138 & 4779 & 6485 & 5158 & 1698 \\
Nov. 1986 & 5800 & 9188 & 7071 & 8655 & 7614 & 961 \\
Dec. 1986 & 4936 & 6719 & 7543 & 8474 & 8245 & 1756 \\
Dec. 1987 & 8393 & 8275 & 8498 & 8132 & 7631 & N.S. \\
Feb. 1986 & 5264 & 5999 & 5450 & 4959 & 5712 & 606 \\
Jan. 1988 & 5335 & 5977 & 7518 & 5955 & 6562 & N.S. \\
Mar. 1987 & 5148 & 6447 & 4046 & 5321 & 4914 & 1827 \\
April 1987 & 2361 & 3274 & 3021 & 2524 & 3496 & 1144 \\
June 1986 & 6587 & 8179 & 8033 & 7339 & 9110 & N.S. \\
May 1988 & 3067 & 3685 & 3840 & 2676 & 4035 & 904 \\
\hline
\end{tabular}


early variety Cuarentena had the greatest percentage green-shell yield, averaging $48.8 \% ; 8542-225$ had the lowest percentage, averaging $41.8 \%$. Percentage of green-shell yield of the other genotypes ranged from 45.5 to $46.4 \%$. Green-shell bean yields were highly correlated with whole pod yields both at the Isabela $\left(0.94^{*}\right)$ and the Fortuna substations $\left(0.91^{*}\right)$. This finding suggests that evaluation of whole pod yield is an adequate measure of green-shell yield potential. 